\title{
Learning to 'Be/Live' in Kathmandu City: Kirat Migrants' Transformation
}

\author{
Indra Mani Rai (Yamphu)* \\ School of Education, Kathmandu University, Lalitpur,Nepal
}

\begin{abstract}
This paper, based on auto/ethnographic inquiry, explores how particular urbanised Kirats (internal migrant ethnic community members in Kathmandu city from the East of Nepal) learn to live in Kathmandu city. The paper argues that the formal education in Nepal, guided by Western modern worldviews as hegemony, is promoting imported instrumental knowledge and skills, which are impractical and less relevant in the job market, particularly in the city context. The paper further argues that the work based learning support them to transform to become particular urban professionals. However, those Kirats are made forced-learners in urban structures for their adaptation in a new context. Such forced-learning is subjugating indigenous knowledge inherited to them from their ancestors and accumulated in their village life.
\end{abstract}

Keywords: Kathmandu City; Forced-learning; Indigenous Knowledge; Auto/ Ethnographic Inquiry; Kirats

\section{Setting the Scene}

My birth and early growth occurred in a Yamphu ${ }^{1} /$ Kirat $^{2}$ family with particular indigenous ways of living and cultural pattern, in a village of North-East of Sankhuwasabha district in Eastern Nepal. Reflecting back in the 1980s -1990s, I remember the living pattern in my ancestral land. The subsistence living was indigenous or natural resource based. Surrounding natural vicinity supported us to fulfil the living requirements whether it was agriculture or wild products (edible wild roots and bulbs). I struggled for living through engagement in cultivation of major crops such as rice, maizeand millet with a pair of bullocks for ploughing two small patches of farmlands and a small dry field. Inadequate foodstuff production from the limited land could not fulfil the food requirement throughout the year in my family. I enjoyed the works in half, full or sometimes in empty stomach. Engagement in grazing animals, collecting fodder, fishing, hunting and so on was usual to me. I lived in a small house with thatched roof. It could not stop the rain from flowing inside. I was not embarrassed by walking here and there with torn clothes. Perhaps, I was brought up in a poverty stricken family. 
Learning to 'Be' in Kathmandu

Back in 1990s, I switched my living to an urban context (Kathmandu city). Higher education as modern facility dragged me from my indigenous world. Nevertheless, initially, my living in Kathmandu city was miserable. My rural indigenous ways of living was totally incompatible with the urban ways of living and lifestyles. I was introvert in nature and did not know how to be familiar and social with other people. My hungry days started with the passage of time. I spent most of the days without adequate food for almost two years. It was in 1992, I started to hunt a job when I completed my intermediate level (i.e. twelfth grade) of education. It was difficult to be placed in an appropriate job. I might be one among many urban dwellers living with economic adversities with insecure livelihoods because of joblessness in Kathmandu (Dahal, 2010). After several attempts, I was recruited in a small private school as a teacher. However, the remuneration was not enough to fulfil my living requirements. Therefore, I left that school, and joined another private school nearby my rented residence. The latter was a bit better in terms of payment. It was not easy for me to adapt in the workplaces through learning pedagogical practices. I continued my teaching profession for some years. It was in 1998, I established a private school which has been providing me with better earning. But how did I learn the actions and activities of these livelihood strategies for the adaptation in the urban context? How did other Kirats learn to live in the urban context when they switched their living? These are the central concerns of this paper.

\section{Methodology}

For the purpose of this paper, I used auto/ethnography as my research methodology, which allowed me to explore, present, and represent (Haynes, 2011, p. 17) both my participants and me as a member of a culture sharing group. It facilitated me to explore the multi-hued account of lived experiences of the self and other Kirats" "culturally embedded identities" (Taylor, Taylor, \& Luitel, 2012, p. 9). I engaged in writing autobiography. Further, it allowed me to understand the cultural world of urban Kirats. In so doing, I engaged meaningfully in the field for extended period of time with three participants including me. It was to understand cultural ways of knowing of those Kirats, who had been residing in Kathmandu city for about two decades. I adopted interview-led ethnography with careful and engaged listening to capture the realities (Forsey, 2010). I was aware that a lot of knowledge exists in other forms that are non-discursive language. I transmitted them through informal observation (Murchison, 2010).

I recorded the conversations and maintained field notes simultaneously. Moreover, I developed each day's field journal on the basis of my field notes, field experiences and memories of the field. Moreover, the journals were descriptive, analytic, and reflective including observational information, micro happenings and activities. Then, I produced evocative thick descriptions of personal and interpersonal experiences. I presented the discerning patterns of cultural experiences through storytelling (Ellis, Adams, \& Bochner, 
10 I. M. Rai (Yamphu)

2011). I crafted the confessional ethnographic tales (Van Maanen, 2011). I crafted stories where the interview process might be part of the story itself. I enrolled my and other participants' experiences creating mixed genres (Ellis, 2004). The next step was to make an interpretation advancing personal views, making comparisons between my interpretations and the literature. Finally, I developed "fruitful ideas, concepts and theories through close exploration of data" (Hammersley \& Atkinson, 2007).

\section{Learning to 'Be' a 'Pedagogue'}

During those days in 1992, it was difficult for me to teach mathematics and science in English as medium of instruction in a private school in Kathmandu city. Perhaps I was not sufficiently shaped by school and university education. However, the continuous attempt of teaching in English as medium of instruction helped me to improve my delivery a bit. I felt a little bit comfortable in English. After one year, I decided to change my workplace. The class observer/examiner appreciated my ways of teaching as well as my English proficiency and employed me as math cum science teacher with a bit better remuneration. As in the process of urban adaptation, I became a private school teacher. I reproduced the same practices there. I used to speak English at school. I cared less about the students' self-expression and conceptualisation of ideas through language. They had less chances to speak Nepali. Otherwise, they were muted. This was a form of linguistic imperialism and domination. English has three forms of power such as intrinsic (high class and standard), extrinsic (textbooks and reference materials) and functional (people-to-people contact) (Phillipson, 1992), which suppresses the use of local language.

The supremacy and domination of English language as medium of instruction threatened the linguistic diversity with less meaningful learning. English language has become a tool for global communication and global culture (Ray, 2007). It was a domination of imported language suppressing the local language. This was structural domination to diversified languages. I realise that the use of English language as a medium of instruction violated the linguistic rights of children from other diversified minority languages (Awasthi, 2004). It might be a form of politics for serving the interest of Western power structures to make homogenisation through linguistic expansion. Nepali schools have been serving the interest of others by imposing the foreign language as medium of instruction, neglecting local languages. This is Western hegemony that has been accepted without resisting.

In addition to the use of foreign language, I used disempowering nature of transmissionists' approach of teaching learning activities. I thought that teaching was transmitting the bookish content to the students through lecture. Most of the time, in a class, the students listened to me watching on the board, noting down some lectured points. I forced them to memorise the formulas and definitions of math and science. Students solved mathematical problems using formula and answered the questions based on what 
were there in the books. These transmissionist pedagogical approaches facilitated to hold on to decontextualised teaching learning activities (Luitel, 2009). I remember that my ways of teaching learning activities were less engaging to students. The students were passive listeners accepting what I told them to do. However, sometimes, my focus would be on small project works. These had little value in the face of dominant "disempowering pedagogical models of listen-repeat-remember-recall and do-what-your-teacher-says" (Luitel, 2009, p. 7). This approach was suppressive to promote contextual pedagogical practices in private schools. This one-size-fits-all approach would compel the students to be passive recipients of imported knowledge.

After four years of continuous engagement in such teacher centred teaching learning activities through English as a medium of instruction, I experienced such disempowering practices in my work places. As of now, I think that the structured and teacher dominant practices including intention of developing English competencies were everything to promote the learning of students. Then I shifted my mind towards establishing a school in partnership with some modified pedagogical practices. I did not have choices of language, which contributed to the reproduction of present power relation in the education system (Bourdieu \& Wacquant, 1992). However, I attempted to employ more student-centred pedagogies in my school. For example, I engaged the student in learning processes providing activities such as project works and group works, allowing them to share their ideas. I managed exposure visits and field studies allowing students to experience the real situations. As this was my own school, I worked hard, and tried to be more proactive, creative and innovative for promoting those practices. This was my tendency of transforming self towards constructivist teacher from instructivist one but I did not leave the instructivist or transmissionist approach of pedagogy totally.

My experiential learning of English as a medium of instruction and transmissionist pedagogical approaches in workplaces (educational institutions) were the processes of forming my identity as a foreign teacher but were the assets for urban adaptation through building better livelihoods. As viewed by Bourdieu, these could be immaterial forms of capitals as resources supporting me to yield material or economic benefits (Thomson, 2008). In other words, I converted these capitals into other forms (Skutnabb-Kangas, 1990) such as financial asset for the adaptation in Kathmandu. Possibly the experiential learning that I gained over time through the engagement in school setting is my capability enhancement (Sen, 2000), which helped me to enhance my livelihoods.

Dominance of English language and decontextualised pedagogical practices are based on Western modern worldviews-such as homogenisation and universalism. However, these practices supported my living through earning to the extent of fulfilling my basic requirements in Kathmandu. Possibly the learning within the school setting marginalised the local cultural values, beliefs, non-verbal and background knowledge (Habermas, 1989, as cited in Ray, 2007). It was due to the structured pedagogical practices set by the school 
authority as power shaped my activities of learning. For me, these were the imported practices and hence were guided by Western modern worldviews. I experienced that the emphasis was largely on transmissible knowledge from the textbooks rather than tacit knowledge through persistent observation at real world experiences. Arguably, it was the process of materialising universalism and homogenisation as Western modern worldviews. It might be due to modern/urban society that has undergone a 'crisis of meaning' as it undermines common-sense 'knowledge' (Ray, 2007, p. 13). Disregarding the knowledge of lifeworld of learners in the processes of learning was likely to deny fostering local knowledge and knowing. In other words, more decontextual nature of learning processes was suppressive to foster indigenous knowledge.

Thus, here, I am in line of what Luitel (2009) argues that the pedagogical practices in Nepali context are guided by narrow views of globalisation as westernisation, and globalisation as universalism. I accepted and adopted these practices in ataken granted manner without challenging. In this sense, it is the hegemony that the existing pedagogical practices are unquestioned and accepted for the good of 'Others'. Such hegemony is likely to exclude one particular dimension of employing indigenous ways of knowing through the process of homogenisation. More so, it might be against the border pedagogy, which offered less the opportunity for surfacing the students' and my feeling about indigeneity as constitutive of my own identity (Giroux, 1991). The pedagogies guided by universalism as western modern worldview were less supportive to excavate students' lived experiences of indigenous world. I feel that the practices could not decenter the learning resources.

I do not mean to say that there were no collaborative and shared learning in the classroom. The practices, however, often disregarded the indigenous ways of knowing. In this sense, this was undemocratic practices subjugating indigenous knowledge and knowing. The school was the 'legitimised' authority contributing to materialise the Western modern worldviews. The school and me could not refuse and hence were silent. In this sense, the adopted practices ignored the experience of marginality. I think, possibly, the border pedagogy could open up the possibility for students and me as a teacher to raise the voices as part of empowerment process, the way of resisting the dominant culture of pedagogies. These are the racists' practices (Giroux, 1991) in Nepali school education system. Let me communicate the lived experiences of Sapmiyungba, bringing into light how he was learning forcefully the practices of living in urban space.

\section{Learning to 'Be' an 'Auditor'}

It was in 1997. Sapmiyungba earned bachelor's degree in commerce. He was recruited in a Chartered Accountant Form. But he was less aware on the practical works of auditing. He found there amiable co-workers of similar age group with almost equal educational qualification. He expressed, "We were co-operative and friendly. We all spoke our common language - Nepali. We discussed in the matters what we felt difficulties in auditing process. 
Learning to 'Be' in Kathmandu $\mid \begin{aligned} & 13 \\ & \mid\end{aligned}$

My senior was also helpful. He would advise me time and again in a friendly manner." He would engage on discussion with his friends sharing his ideas and listening to his coworkers' views. He remembered one of the events, "I was unaware that the dates of voucher and corresponding bills should have matched or be of the same date. My supervisor found the mismatched dates and hence suggested correcting it. I never repeated such mistakes." He learnt many of the knowledge and skills of auditing processes through sharing ideas among the co-workers. He enjoyed the friendly guidance of his boss. Sapmiyungba further expressed, "I grew in Chettri and Bahun community. I know their culture. I don't know my own language even being a member of and belonging to the Kirat community. My mother tongue is Nepali. I have largely adopted Hindu culture. I think that the linguistic and cultural intimacy with the co-workers in the second Charter Accountant Form helped me to learn better auditing processes."

Through conversation with Sapmiyungba, I knew that the familiarity of culture and language among the co-workers in the workplace played a crucial role in leaning professional skills. He engaged in work-based learning creating opportunities of participating himself meaningfully in learning auditing skills. He developed "the ability to ask and answer important questions, to communicate and work with others in learning, and to create new knowledge" (Trilling \& Fadel, 2009, p. 49). His learning remained productive in his community of learners/co-workers. He shared knowledge and skills in their communities of work and professional practices. Thus, for Sapmiyungba, his co-workers provided conducive learning context. Agreeing with the idea of Vygotsky, the working context with familiar language and culture facilitated him to be more active, interactive and shared learner (Turuk, 2008). Perhaps, this was collaborative learning approach of professional skills of auditing. The language facilitated to engage in constructing new meaning of experiences of learning. However, the self-identity mattered in the learning process in the workplace of Sapmiyungba. Thus, the identity as labelling one from the other cultural and linguistic groups might play a crucial role in learning in the workplace.

Possibly Sapmiyungba raised his consciousness through such linguistic interaction (Kreber, 2012) with the co-workers. The shared language facilitated me to develop amiable relationships with the co-workers. The amiability helped to bind together for sharing ideas among the learners. Arguably, the common language supported to express feeling and perception among the professionals as they had sensibility of togetherness or own-ness. This sensibility of belongingness (emotionality of being accepted as a member of a group of people) might be the Nepaliness. This language was one of the forces that promoted work based learning meaningfully. More so, Nepali nationalism constructed through the use of Napali language and culture among the co-workers facilitated to enrich work based experiential learning of Sapmiyungba's professional practices. This was a process of adaptation in the urban context. It improved professional skills through work based learning and strengthened earning and livelihoods. 
In this context, Sapmiyungba engaged in gaining knowledge and skills of auditing as a border-crosser. I am not talking about the physical border. It is rather cultural borders, historically constructed and socially organised that serve to either limit or enable particular identities (Giroux, 1991) for learning in the workplace. He crossed over into borders of meaning, maps of knowledge, social relations, and values that negotiated. The learning took place under shifted context, identity, and power. Possibly, he engaged in such contexts in a way of remapping, reterritorialising and decentering the knowledge (Giroux, 1991). He negotiated cultural borders with the co-workers, gaining personal experiences of workplace skills.

The sense of collectivity and mutual support in the workplace of Sapmiyungba was likely to clash and grapple with the Western modern practices of auditing, which he had learnt theoretically in the university setting. For example, he expressed, "I feel that I got only theoretical knowledge in the university. I had never seen even vouchers and bills. I realised that I studied all the things later when I practically engaged on these processes." For Sapmiyungba, theory oriented formal education gained through university was less supportive for engaging in his professional activities meaningfully. Possibly, the impractical knowledge based on books might not facilitate him to adapt easily in his real workplaces. It was thus the decontextualised learning in university, relying more on bookish knowledge was less empowering to Sapmiyungba.

It may be due to the fact that formal education has been structured and limited by the unequal exercise of power. It might be a "political process in which certain interests and agendas are always pursued at the expense of others, in which curriculum inevitably promotes some content as an exercise of the power" (Taylor \& Cranton, 2012, p. 135). Possibly there was less emphasis on the existing educational system through which he acquired knowledge and skills. It was less related to his life (Semali, 1999) to be adapted in the urban space. Possibly, due to power structures there exists epistemic oppression against local ways of knowing through Westo-centric curriculum (Semali \& Kincheloe, 1999). These power structures are clearly visible in Nepali education system that determines what truth is and what is not.

The imported knowledge system has subjugated the contextual local knowledge. The structural curriculum with greater emphasis on instrumental knowledge and skills marginalised this body of knowledge. It has ignored local knowledge through adoption of Western science and its episteme (Semali \& Kincheloe, 1999). Perhaps the learning of auditing works forced to subjugate these indigenous knowledge systems. The knowledge systems associated with indigenous livelihood practices, which passed down from his ancestors and experiences he gained in his village life remained under suppressed position. Such knowledge systems were unrelated and almost unused in the urban context for building livelihoods. However, he developed the experiential knowledge and skills of 
Learning to 'Be' in Kathmandu $\mid 15$

auditing to adjust in complex social structures of modern age in urban context to affirm his life.

Can I say that the modern education system positioned him to be informed at meaningless auditing knowledge and skills? It denied experiencing the phenomena (Arenas, Reyes, \& Wyman, 2007). The knowledge transmitted to him might be impersonal and abstract with little or no relationships with his professional life. The system privileged to impart imported instrumental knowledge. The transmission of fragmented and bookcodified knowledge was less useful in the professional practices of Sapmiyungba. The education system compelled him to be rote learner but urban world looked for competitive one (Koirala, 2003) with practical knowledge and skills of auditing. Possibly, this was the reason he learnt many of auditing knowledge and skills only when he engaged in his workplace.

\section{Learning to 'Be' a 'Pressman'}

The days were of March, 2015. After several years of experiences gained through the press works in others' companies, Soyanbasa started his own printing press. I saw him a bit busy and had little time for talking with me. Throughout the time I stayed there, he moved his lips and hands together. I keenly observed his entrepreneurial business activities. He worked like a machine. His hands moved automatically while working with machines and papers. He talked to his clients and tried to convince them for the dissatisfaction on earlier works of printing. I thought that he was a bit tactical. Aclient said, "Please calculate the total cost of printing". He held his calculator and calculated the cost. He replied, "Its Rs. 9000 for only developing plates." The client was surprised and said, "How?" He convinced the client calculating his rates of each page and labour cost. He tried to maintain the transparency of his work. He immediately said, "You see, it is difficult for me to work as we have load shedding and fuel crisis." He tried to get empathy from the client. He interacted in a friendly manner so that his language was mild but committed. He promised to produce quality work within the fixed timeframe. I felt that he had good interpersonal communication skills.

It may be another day of the same month. I asked Soyangbasa, "How did you learn these skills?" He expressed his experiences, "In the initial days of my arrival in Kathmandu, I lived with a friend from my own village who worked in a press company. I would go to his office to pass my leisure time. I would observe the press work. Later, I started to work in the same company. I made mistakes at the beginning but gradually I learned works such as developing negatives, pasting, cutting and so on." He gained practical skills of operating technologies of his press company through observations and self-engagement in actions. These were the technical skills (Trilling \& Fadel, 2009) that he learned through correcting errors, committed in his actions. Moreover, he engaged and interacted with his clients with unintentional learning of interpersonal skills. Possibly his engagement on experiencing the 
press works and reflecting on his own actions helped him to visualise the new opportunities of learning. This was his work-based learning with reflective practices of experiences gained through continuous involvement in the works of press. Perhaps, he was involved in constant problem solving processes and activities (Watkins, Marsick, \& Faller, 2012).

The technical knowledge and skills Soyangbasa gained through his engagement in work places helped him to be an independent entrepreneur. Perhaps, he was guided by what Habermas sees a 'technical interest' (Grundy, 1987, p. 16) by which he oriented to engage in technical works giving rise to instrumental actions. For example, he engaged with the printing machines as his day to day activities. These actions were a part of living activities. Possibly, these activities were generated by "instrumental knowledge as the technologies" (Cranton, 2002, as cited in Natanasabapathy, Bourke, \& Joshi, 2011, p. 64) adopted by him. On the other hand, his engagement with technologies in his press company was expert culture, emerged from scientific discovery on which he enhanced his technical knowledge and specialisation on it (Ray, 2007). The scientific knowledge he gained through his work based experiences enabled him to establish social relationships in the urban space. He maintained connectivity or networks with his clients. However, gaining scientific/expert knowledge was forceful to him, which was created by urbanism for materialising the process of globalisation. The technical knowledge dominated the indigenous knowledge that he accumulated as the given space did not allow him to use such body of knowledge and skills. City as modern society is a context in which the indigenous knowledge remains devalued (Ray, 2007).

As informed by the tale of Soyangbasa, he generated "new knowledge traits that emerged out through unintentional inventions (trial and error method)" (Gupta, 2011, p. 57) in his workplace for building his livelihoods in a new urban context. It was his practice through which he tried to solve the problems he faced in his work and discovered the new skills through correcting errors (Jarvis, 2012). More so, he integrated the technology knowledge (Terry, 1997) with interpersonal skills of interacting with other people (clients), which helped him to foster his business. This skill helped him to develop networks and connectivity with his clients. The interpersonal skills developed in the work place were for "understanding and accommodating cultural and social differences" (Trilling \& Fadel, 2009, p. 50). Perhaps, Soyangbasa's strategy of maintaining relationship with the diversified urban people allowed him to make "understandings on the environment through interaction based upon a consensual interpretation of meaning" (Grundy, 1987, p. 14). He learnt this skill through his experiences. The consequence of this practical interest was the action of communication or symbolic interaction with people with consensual norms. Possibly this was "communicative knowledge" of developing relationships with the people and "emancipatory knowledge" of life skill learning (Cranton, 2002, as cited in Natanasabapathy et al., 2011, p. 64). The achievement of communicative skills helped to achieve better livelihoods for his liberation from vulnerability of livelihoods. 
Learning to 'Be' in Kathmandu $\mid 17$

\section{Forced Learning and Towards Transformation}

Those urbanised Kirats were adult learners. The work-based learning of those Kirats was a form of informal learning of work-based knowledge and skills. Merriam (2001) argues that adult learners are self-directed, self-motivated and autonomous. However, for me, those urbanised Kirats were less self-directed and autonomous work-based learners in their workplaces. This is because their workplaces are the newer urban social settings or learning environment, which forced them to learn new living knowledge and skills. This was their situated learning which focused on day to day learning through interaction with the co-workers. "An important part of situated learning is the construction of knowledge within the social and cultural circumstances in which learning occurs, namely the social context' (Clus, 2011, p. 359). 'Urban' and 'modern' are blurring concepts. In this sense, the modern social context is shaping the learning of work based knowledge and skills of those urbanised Kirats.

In addition, Mezirow (2000) believes that adult learners have autonomy to act and judge independently of external constraints. The urbanised Kirats were less autonomous. They were rather forced to learn those living strategies by invisible forces of urbanism or modernisation. They might not have achieved greater autonomy in acquiring abilities to participate freely and fully in rational discourse of their learning activities. The modern social structures in urban space compelled them to learn those livelihood activities for their adaptation in urban context for fulfilling their livelihood needs. In this sense, their work-based learning was positioned structurally. They learned modern means or strategies of living. They were forced to discard their indigenous practices of living, and hence the culture. For me, such context-based learning was a form of hegemony that those urbanised Kirats accepted without any resistance and questioning.

On the one hand, within the dominated context, urbanised Kirats were transmitting their work experiences in their own work places demonstrating their potentiality, which was a way to self-liberation from livelihood susceptibility. Their stress was on the self-education of mind through understanding the practices. They learned their professional activities through generated meanings of their work experiences. Possibly they raised awareness through listening, thinking and experiencing their world (Dong, 2003; Freire, 1993). They created their own space of living, which played crucial roles for liberating them as independent being for living in the urban world. This was advantageous to them to promote their living. However, these learning processes might have discouraged the indigenous knowledge promotion that they accumulated and/or experienced during their rural growth. In this sense, indigenous knowledge remained under subjugated position denying flourishing (Semali \& Kincheloe, 1999) under Western modes of livelihood activities.

As a product of modernisation, urbanised Kirats shifted their ideas and beliefs through self-learning of urban means of living. They altered their thinking and behaviours in 
the process of learning their work skills. The critical awareness and development of consciousness (Taylor \& Cranton, 2012) from work-based experiences facilitated them to change their living to be adapted and adjusted in the urban context. This transformation helped them for becoming. Perhaps they transformed themselves through personal interpretation or meaning making of their work experiences and hence developing selfperspective upon. This transformation was knowledge creation on which the livelihoods were dependent (Chemjong, 2003). This transformation in those urbanised Kirats facilitated to generate income to the extent of supporting their better living in Kathmandu city.

The experiences they have gained in the urban setting might have shaped their perspectives and actions. Perhaps this was due to engagement in the "reflective discourse" for assessing critically the earlier assumptions or interpretation and beliefs (Mezirow, 2012, p. 78). In other words, sharing of ideas and perspectives among the people with whom they interacted in their work places shaped their knowledge and skills. Possibly, this was the process what Mezirow (2000) argues- the engagement of making meaning and reassessing their orientation through critical or self/reflection (Dirkx, 1998; Milheim, 2008). Urbanised Kirats might have changed their world views and day to day activities or actions through reflective learning as a form of self-transformation (Mackeracher, 2012). Perhaps, this was the process of interpreting their predispositions and presuppositions of accepting or rejecting taken-for-granted ideas.

Even in structurally dominated world, possibly, personal shift occurred among urbanised Kirats in different phases, forming a path of transformation. The path might have moved through the stage of not knowing or the stage of ignorance to the stage of knowing, and then becoming or the stage of applied action (Natanasabapathy et al., 2011). They did not limit themselves acquiring knowledge and skills through work-based experiences. They rather transferred such knowledge and skills in their workplaces for generating their livelihoods. The stage of experiencing the professional practices was a transitional phase in the path of transformation. They crossed the border of transitional stage of acquiring knowledge and skills towards application of such knowledge and skills in their working context. In this sense, they were on the path of transformation, which was not mere knowing the world. It is rather using the knowledge and skills in practical terms. Their transformation was their behavioural change as learners, possibly in a meaningful manner for generating livelihoods.

\section{Conclusion}

I came to the conclusion that Nepali education system is less practical. Learners hardly utilise their knowledge and skills in their workplaces for building their livelihoods. The education system guided by Western modern worldviews (such as universalism, structured education system, centrality and homogenisation) as hegemony is providing less relevant knowledge and skills. This has promoted imported and de/contextual instrumental 
Learning to 'Be' in Kathmandu $\mid 19$

knowledge. Instrumental knowledge as a colonial tool has been legitimised by the Nepali education system. This modern decontextualised education is almost non-applicable for those urbanised Kirats, which forces them to learn practical knowledge and skills through work-based experiences. The formal education shapes them in a way with universal truths. The job market, on the other hand, demands different workforce. The imported knowledge through one-size-fits-for-all process marginalises them for getting employment opportunities. However, it may be useful in the context of reproduction, where the jobs are largely based on instrumental knowledge.

The work based learning that has occurred in a newer urban context has subjugated indigenous knowledge systems which are often inherited from family/lineage/community in the village. This body of knowledge is subjugated and hence unrelated, unused and possibly devalued. This is a structural denial of use of indigenous knowledge systems that they have acquired in rural context. The modern social setting is shaping modern knowledge and skills for adaptation in the urban context. In this sense, the urbanised Kirats are forcedlearners rather than self-directed, self-motivated and autonomous ones. They are less autonomous work-based learners. They are rather forced to learn those living strategies by invisible forces of urbanisation or modernisation. The modern social structures of urbanism compel them to learn those livelihood activities. Such forceful work-based learning is an imposition for structural learning. Thus, such learnings are forms of hegemony, which Kirats accept without visible resistance.

\section{Notes}

'Yamphu is one of the linguistic groups under the ethnonym developed from the given title 'Rai' and Rai is an ethnic group under Kirat. Therefore, Yamphu is one of the Kirat groups with distinct language and culture, clustering in some of the districts of Eastern Nepal.

${ }^{2}$ The Kirat or Kirati or Kiranti or Kirant people are indigenous ethnic groups of the Himalayas extending eastward from Nepal.

\section{References}

Awasthi, L. D. (2004). Exploring monologual education practices in multilingual Nepal. (Unpublished doctoral dissertation). Denish University of Education, Copenhagen, Denmark.

Arenas, A., Reyes, I., \& Wyman, L. (2007). When indigenous and modern education collide. World Studies in Education, 8(2), 33-64.

Bourdieu, P., \& Wacquant, L. J. D. (1992). An invitation to reflexive sociology. Cambridge, England: Polity Press.

Clus, M. L. (2011). Informal learning in the workplace: A review of the literature. Australian Journal of Adult Learning, 51(2), 355-373. 
20 I. M. Rai (Yamphu)

Dirkx, J. M. (1998). Transformative learning theory in the practice of adult education: An overview. PAACE Journal of Lifelong Learning, 7, 1-14.

Dong, Y. (2003). Buddhism: Education for a modern world. Hsi Lai Journal of Humanistic Buddhism, 4, 284 - 293.

Dahal, K. (2010). Urban poverty: A study of income patterns and processes of the poor families in Kathmandu. Banking Journal, 1(1), 29 - 45.

Ellis, C. (2004). The ethnographic I: A methodological novel about autoethnography. London, England: Alta Mira Press.

Ellis, C., Adams, T. E., \& Bochner, A. P. (2011). Autoethnography: An overview. Forum: Qualitative Social Research, 12(1), 1-17.

Freire, P. (1993). Pedagogy of the oppressed. London, England: Penguin Books.

Forsey, M. G. (2010). Ethnography as participant listening. Ethnography, 11(4), 558-572.

Grundy, S. (1987). Curriculum: Product or praxis. London, England: The Falmer Press.

Giroux, H. A. (1991). Border pedagogy as postmodern resistance. In H. A. Giroux (Ed.), Postmodernism, feminism, and cultural politics: Redrawing educational boundaries (pp. 358-363). New York, NY: State University of New York Press.

Gupta, A. D. (2011). Does indigenous knowledge have anything to deal with sustainable development? Antrocom Online Journal of Anthropology, 7(1), 57-64.

Haynes, K. (2011). Tensions in (re)presenting the self in reflexive autoethnographical research. Qualitative Research in Organizations and Management: An International Journal, 6(2), 134-149.

Hammersley, M., \& Atkinson, P. (2007). Ethnography: Principles in practice (3rd ed.). New York, NY: Routledge.

Jarvis, P. (2012). Learning from everyday life. Human and Social Studies Research and Practice, 1(1), 1-20.

Kreber, C. (2012). Critical reflection and transformative learning. In E. W. Taylor \& P. Craton (Eds.), The handbook of transformative learning: Theory, research and practice (pp. 323 - 341). San Franscisco, CA: Jossey- Bass.

Koirala, B. N. (2003). Managing paradoxes: Education for the sustained future. In B. B. Bhandari \& O. Abe (Compiled), Education for sustainable development in Nepal: Views and visions (pp. 151-158). Tokyo, Japan: Institute for Global Environmental Strategies (IGES) and School of Environmental Management andSustainable Development (SchEMS)/Nepal.

Luitel, B. C. (2009). Culture, worldview and transformative philosophy of mathematics education in Nepal: A cultural philosophical inquiry (Unpublished doctoral dissertation). University of Curtin, Australia. 
Mackeracher, D. (2012). The role of experience in transformative learning. In E. W. Taylor \& P. Cranton (Eds.), The handbook of transformative learning: Theory, research, and practice (pp. 342-354). San Francisco, CA: Jossey-Bass.

Milheim, K. L. (2008). Learning through reflective practice: Professional development of adult basic education program managers (Unpublished doctoral dissertation). The Pennsylvania State University, Pennsylvania.

Merriam, S. B. (2001). Andragogy and self-directed learning: Pillars of adult learning theory. New Directions for Adult and Continuing Education, 89, 3-13.

Mezirow, J. (2000). Learning to think like an adult. In J. Mezirow (Ed.), Learning as transformation: Critical perspective on a theory in progress (pp. 3 - 33). San Francisco, CA: Jossey-Bass.

Mezirow, J. (2012). Learning to think like an adult: Core concepts of transformative theory. In E. W. Taylor \& P. Craton (Eds.), The handbook of transformative learning: Theory, research and practice (pp. 73 - 95). San Francisco, CA: Jossey-Bass.

Murchison, J. M. (2010). Ethnography essentials: Designing, conducting, and presenting your research. San Franscisco, CA: Jossey-Bass.

Natanasabapathy, P., Bourke, J., \& Joshi, R. (2011). Exploring transformative learning in the open and distance learning environment. Philosophy of Education Society of Australasia Conference. Retrieved fromscholar.google.com/citations? user $=i 2 y O_{-}$ $38 A A A A J \& h l=e n$

Phillipson, R. (1992). Linguistic imperialism. Oxford, England: Oxford University Press.

Ray, L. (2007). Globalization and everyday life. London, England: Routledge.

Sen, A. (2000). Development as freedom. New Delhi, India: Oxford University Press.

Skutnabb-Kangas, T. (1990). Language, literacy and minorities. London, England: The Minority Rights Group.

Semali, L. M. (1999). Community as classroom: (Re)valuing indigenous literacy. In L. M. Semali \& J. L. Kincheloe (Eds.), What is indigenous knowledge? Voices from the academy (pp. 95 - 118). New York, NY: Falmer Press.

Semali, S. M., \& Kincheloe, J. L. (1999). Introduction: What is indigenous knowledge and why should we study it? In L. M. Semali \& J. L. Kincheloe (Eds.), What is indigenous knowledge? Voices from the academy (pp. 3 - 58). New York, NY: Falmer Press.

Taylor, E. W., \& Cranton, P. (2012). The handnook of transformative learning: Theory, research, and practice. San Francisco, CA: Jossey-Bass.

Terry, P. R. (1997). Habermas and education: Knowledge, communication and discourse. Curriculum Studies, 5(3), 269-279. 
22 I. M. Rai (Yamphu)

Trilling, B., \& Fadel, C. (2009). 21st century skills: Learning for life in our times. San Francisco, CA: Jossey Bass.

Taylor, P. C., Taylor, E. L., \& Luitel, B. C. (2012). Multi-paradigmatic transformative research as/for teacher education: An integral perspective. In B. J. Fraser, K. Tobin, \& C. J. McRobbie (Eds.), International handbooks of education (pp. 373 - 387). New York, NY: Springer.

Thomson, P. (2008). Field. In M. Grenfell (Ed.), Pierre Bourdieu: Key concepts (pp. 67-81). New Delhi, India: Rawat Publications.

Turuk, M. C. (2008). The relevance and implications of Vygotsky's sociocultural theory in the second language classroom. Annual Review of Education, Communication, and Language Sciences, 5, 244-262.

Van Maanen, J. (2011). Tales of the field: On writing ethnography (2nd ed.). Chicago, IL: The University of Chicago Press.

Watkins, K. E., Marsick, V. J., \& Faller, P. G. (2012). Transformative learning in the workplace: Leading learning for self and organizational change. InE. W. Taylor \& P. Craton (Eds.), The handbook of transformative learning: Theory, research and practice (pp. 373-387). San Francisco, CA: Jossey-Bass. 